\title{
Bush favours research at Pentagon and NIH
}

\section{Colin Macilwain, Washington}

Military research is up, environmental work is drastically cut, and the National Institutes of Health (NIH) will grow while the rest of civilian science is basically frozen. That is the firmly conservative outline of George W. Bush's first federal budget proposal, details of which were released on 9 April.

The Bush budget for research and development (R\&D) reverses the most important trend of the Clinton years, boosting military research by $\$ 2.5$ billion - for as yet unspecified purposes - and reducing the civilian share of the $\$ 95$ billion R\&D spend.

But even as Bush rolled out his numbers on the White House lawn, critics were pointing out that Congress is unlikely to leave many of them intact by the time the 2002 fiscal year begins on 1 October. Just last week, the Senate passed non-binding resolutions that would add more than $\$ 2$ billion to Bush's proposals for civilian science.

Announcing plans to increase the NIH's budget by $\$ 2.8$ billion to $\$ 23.2$ billion next year, Tommy Thompson, the health secretary, pledged that the administration would seek an additional $\$ 4$ billion the year after.

\section{Boost for AIDS vaccines}

Under the president's plan, the NIH would spend $\$ 12.5$ billion on research project grants in 2002, an increase of $13 \%$ over 2001. Thompson highlighted the NIH's plans to increase research on AIDS vaccines by more than a quarter to $\$ 357$ million, out of $\$ 2.5$ billion of research that he said is related to AIDS.

But several scientific groups say that the allocation for the NIH is not enough. Mary Hendrix, president of the Federation of American Societies for Experimental Biology, called it a "great start" and said that the federation would work with Congress to obtain a $\$ 3.4$ billion increase by October.

It was a very different story at the National Science Foundation, which funds most non-biomedical research at US universities. Here a basically flat budget of $\$ 4.5$ billion left director Rita Colwell with little room for manoeuvre.

As the NSF budget is reshuffled to accommodate some modest new activities, including a \$20 million mathematics initiative, the rest of its research budget will be severely restrained. The amount available for standard, peer-reviewed NSF grants to individual scientists will slip by $0.5 \%$, and the budget for new research equipment falls by a fifth, to $\$ 96$ million.

The number of new awards granted during 2002 could actually dip if the agency concludes that NSF grants should be larger and last longer, says Mark Marin of Lewis-Burke Associates, a Washington-based lobby firm whose clients include research universities.

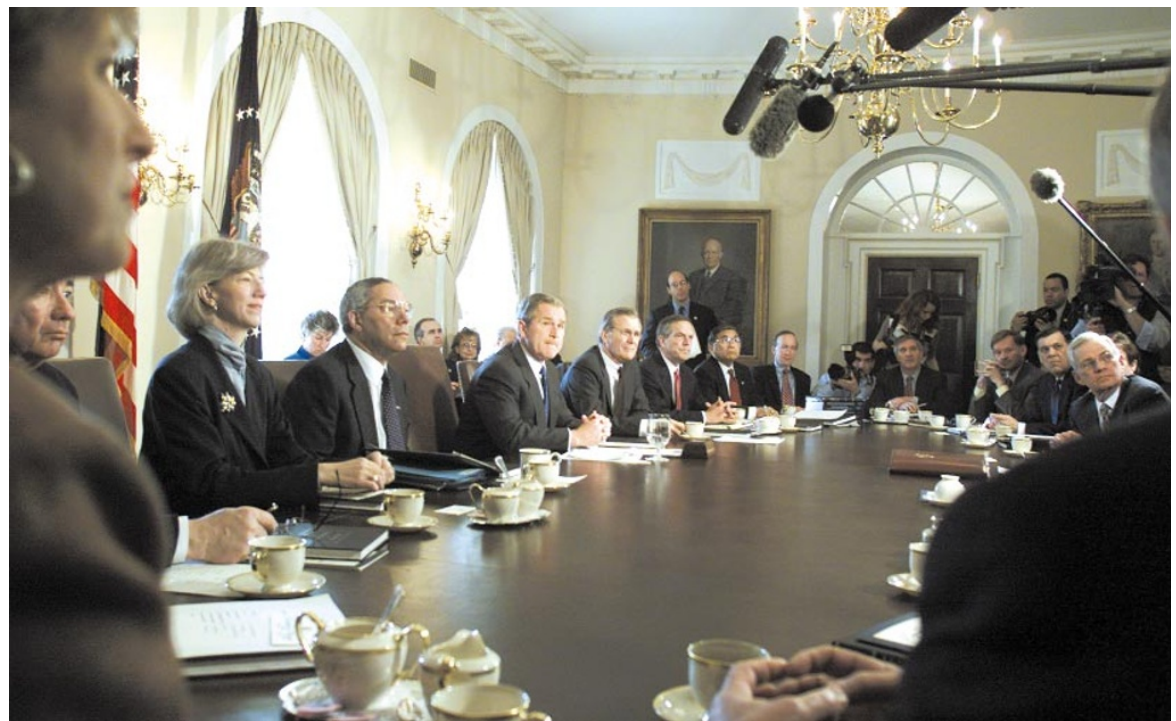

Conservative approach: George W. Bush and his cabinet reveal their proposals for the 2002 budget.

The other highlight in the NSF's budget is a new \$200 million initiative, using money from existing NSF programmes, to tie school education in maths and science more closely with the universities.

Sam Rankin, associate director of the American Mathematical Society, says he is grateful for the $\$ 20$ million in the new mathematics research programme - but noted that it falls short of expectations (see Nature 407, 931;2000).

At NASA, a proposed 2\% increase will take the budget to $\$ 14.5$ billion, although this will not pay for many new initiatives most of the space agency's activities will be funded at pretty much this year's level. But the agency's five-year budget plan was used by the Bush administration to spell out its space priorities.

Space science fares well in this plan, rising from $\$ 2.45$ billion next year to $\$ 3.6$ billion in 2006. Most of this increase would go on new missions. NASA Administrator Dan Goldin says the White House cancellation of a nearterm Pluto mission - which could yet be reinstated by Congress - "will set us back a little". But he adds that a new advanced propulsion initiative, worth $\$ 310$ million over five years, would open new possibilities for exploring the outer planets.

The Department of Energy (DoE), which funds most physics research in the United States, also offered a flat level of funding for next year - to the chagrin of physicists.

"The overall budget is simply not adequate," says Michael Lubell, spokesman for the American Physical Society. With rising power costs and salaries, "a lot of stuff is going to go", he says.

The Bush budget proposal allows no increase at all for nuclear physics and just over $1 \%$ increase for high-energy physics and basic energy sciences.

Lobbyists complain that the budget does not match Bush's statement - speaking to newspaper editors on 9 April - that "basic research gets big increases" in his budget. "They ought to have the guts to say what they're doing," says Lubell.

\section{Energetic cuts}

But other sciences fare even worse at the DoE, with the biological and environmental research division losing $8 \%$ of its 2001 budget. Energy secretary Spencer Abraham also cut funding for renewable energy technologies by $36 \%$, observing that they were "not in focus with where industry was headed".

The department's nuclear weapons research programmes would grow by about $5 \%$, to $\$ 5.3$ billion, with Abraham pledging to resume production of plutonium triggers, which stopped in 1989. Programmes aimed at restraining nuclear proliferation, including aid to Russian weapons labs, are cut by $12 \%$.

The rest of the budget contains aggressive cuts in environmental science. Research at the Environmental Protection Agency, for example, is reduced by more than a fifth, to $\$ 707$ million. The agency's research on clean air and clean water is cut back by a third.

The National Oceanic and Atmospheric Administration - an important player in climate change and ocean research - loses $10 \%$ of the $\$ 365$ million that its main science office has to spend this year.

And the United States Geological Survey loses about $8 \%$ of its 2001 budget. Its biology division falls from $\$ 164$ million to $\$ 152$ million and its water resources division plunges by almost a quarter, from $\$ 202$ million to $\$ 159$ million.

Additional reporting by Matthew Davis, Corie Lok, Tony Reichhardt and Paul Smaglik. 